\title{
IMPLEMENTASI PENGENDALIAN DAN PELAPORAN KAS YAYASAN KASIH MANDIRI BERSINAR
}

\author{
Henny $^{1}$, Margarita Ekadjaja² \\ ${ }^{1}$ Jurusan Akuntansi, Universitas Tarumanagara \\ Email: henny@fe.untar.ac.id \\ 2 Jurusan Manajemen, Universitas Tarumanagara \\ Email: rita_e11510@yahoo.com
}

\begin{abstract}
ABSTRAK
Tujuan dari Pengabdian Kepada Masyarakat (PKM) ini adalah pelatihan implementasi pengendalian dan pelaporan kas Yayasan Kasih Mandiri Bersinar. Hal ini diharapkan agar mereka dapat meningkatkan pemahaman tentang pengendalian dan pelaporan kas yang merupakan tahap lanjutan dari penyusunan laporan keuangan perusahaan jasa yang telah mereka pelajari sebelumnya pada semester lalu. Target khusus dalam kegiatan ini adalah anak-anak jalanan yang sedang belajar di SMA/SMK dan dibina oleh Yayasan Kasih Mandiri Bersinar sehingga dapat melatih kemampuannya di mata pelajaran akuntansi terutama tentang pengendalian dan pelaporan kas, sehingga sukses dalam pendidikan di sekolah dan pada saat bekerja di perusahaan. Pencapaian target ini dapat dilakukan dengan cara memberikan kiat-kiat untuk solusi permasalahan mereka dalam memahami pengendalian dan pelaporan kas. Metode yang dipakai dalam kegiatan ini adalah metode penjelasan materi pengendalian dan pelaporan kas, serta simulasi atau praktek dalam memahami pengendalian dan pelaporan kas tersebut. Pelaksanaan kegiatan ini berjalan dengan baik dimana para peserta aktif bertanya kepada tim pelaksana dan mampu mengerjakan latihan soal yang diberikan.
\end{abstract}

Kata Kunci: Implementasi, Pengendalian, Pelaporan, Kas

\section{PENDAHULUAN}

Pengabdian Kepada Masyarakat ini merupakan kelanjutan dari semester sebelumnya tentang akuntansi dasar dan penyusunan laporan keuangan perusahaan jasa yang dirinci lebih dalam mengenai akun-akun dari laporan keuangan yang dimulai dari akun yang paling likuid yaitu kas. Perusahaan perlu menciptakan pengendalian khusus untuk kas karena kas mudah disembunyikan, relatif lebih mudah dicuri, dan paling sering disalahgunakan melalui kecurangan. Pengendalian terhadap kas meliputi pengendalian penerimaan kas dan pengeluaran kas (Dewi et al., 2017:162).

Kas (Weygandt et al., 2016:295-298) adalah aset yang paling cepat dikonversi ke jenis aset yang lain, sehingga kas adalah aset yang paling rentan terjadinya aktivitas kecurangan. Oleh karena itu, perlu adanya pengendalian kas untuk menjaga kas dan memastikan keakuratan pencatatan akuntansi kas, keefektifan pengendalian internal atas kas adalah hal yang paling kritis. Salah satu laporan keuangan (IAI, 2016:1.11) adalah laporan posisi keuangan dimana informasi yang disajikan dalam laporan tersebut menyajikan pos kas dan setara kas. Menurut Setiawan (2013:4548), laporan neraca/posisi keuangan yaitu laporan yang menunjukkan harta, liabilitas, dan modal pada suatu waktu tertentu. Kas merupakan harta yang harus dilaporkan dalam neraca.

Pelatihan tentang implementasi pengendalian dan pelaporan kas inilah yang merupakan salah satu kegiatan Pengabdian Kepada Masyarakat (PKM) yang harus dilakukan guna memenuhi permintaan dari anak-anak SMA/SMK Yayasan Kasih Mandiri Bersinar dalam meningkatkan prestasi mereka pada mata pelajaran akuntansi dan membantu pengendalian dan pelaporan kas di Yayasan Kasih Mandiri Bersinar. Hal ini merupakan pelaksanaan misi pendampingan berkala bagi anak-anak dan remaja seperti di stasiun, terminal dan daerah kumuh, maka Yayasan Kasih 
Mandiri Bersinar merencanakan program di tahun 2018 adanya kerja sama dengan pihak luar (eksternal) untuk memberikan pengetahuan di bidang pendidikan bagi anak-anak dan remaja jalanan. Kerja sama yang dilakukan ini salah satunya kerja sama dengan Universitas Tarumanagara. Oleh karena itu, Yayasan Kasih Mandiri Bersinar mengundang dosen dari Fakultas Ekonomi Universitas Tarumanagara agar memberikan pelatihan tentang implementasi pengendalian dan pelaporan kas bagi anak-anak yang tinggal dan dibina serta dibiayai sekolahnya di SMA/SMK oleh Yayasan Kasih Mandiri Bersinar. Hal ini dilakukan untuk menunjang pendidikan di sekolahnya masing-masing.

Yang menjadi target sasaran dalam melaksanakan misi pendampingan berkala adalah anakanak Yayasan Kasih Mandiri Bersinar, yang merupakan program dari Yayasan Kasih Mandiri Bersinar di tahun 2018. Sedangkan tujuan dari Pengabdian Kepada Masyarakat (PKM) ini adalah pelatihan implementasi pengendalian dan pelaporan kas di Yayasan Kasih Mandiri Bersinar. Hal ini diharapkan agar mereka dapat meningkatkan pemahaman tentang implementasi pengendalian dan pelaporan dan yang merupakan tahap lanjutan dari penyusunan laporan keuangan perusahaan jasa yang telah mereka pelajari sebelumnya pada semester lalu.

\section{Tinjauan Pustaka}

Pengendalian internal (Yuniarwati et al., 2017:168-169) adalah proses yang dirancang untuk memberikan keyakinan memadai yang berkaitan dengan kegiatan operasi, pelaporan dan kepatuhan. Tujuan pengendalian internal (Dewi et al., 2017:151) adalah untuk melindungi aset, meningkatkan keandalan catatan akuntansi, meningkatkan efisiensi operasi dan memastikan kepatuhan terhadap peraturan perundang-undangan yang berlaku. Komponen utama dalam pengendalian internal (Yuniarwati et al., 2017:169) adalah: 1) Pengendalian lingkungan: merupakan tanggung jawab manajemen puncak untuk menjaga integritas. Aktivitas yang tidak sesuai peraturan dan hukum tidak akan ditoleransi; 2) Resiko: perusahaan harus mengidentifikasi dan menganalisis berbagai faktor yang menimbulkan resiko bagi bisnis dan menentukan bagaimana mengelola resiko; 3) Pengendalian aktivitas: manajemen harus merancang kebijakan dan prosedur untuk mengatasi resiko spesifik yang dihadapi perusahaan; 4) Informasi dan komunikasi: sistem pengendalian internal harus mencakup dan mengkomunikasikan semua informasi terkait baik ke bawah maupun ke atas dalam struktur organisasi serta mengkomunikasikan informasi ke pihak eksternal yang berkepentingan; 5) Pengawasan: sistem pengendalian internal harus dipantau secara berkala dan hasil pengawasan dilaporkan ke manajemen puncak dan/atau dewan direksi.

Pada lima komponen utama dalam pengendalian internal lebih ditekankan pada kontrol aktivitas karena kegiatan ini merupakan inti dari penentuan resiko kecurangan dan sangat bervariasi tergantung dari delegasi tanggung jawab manajemen dalam menghadapi resiko, ukuran dan sifat perusahaan. Terdapat enam prinsip dalam pengendalian aktivitas (Yuniarwati et al., 2017:169), yaitu: 1) Pembentukan tanggung jawab: dalam setiap kegiatan yang dilaksanakan harus ada satu orang yang bertanggung jawab. Misalnya jika terjadi kehilangan dalam saldo uang di kas register, maka kasir harus bertanggung jawab; 2) Pemisahan fungsi: ditempatkan individu berbeda untuk kegiatan yang berhubungan. Kegiatan yang terpisah antara yang menyimpan asset dengan yang membuat catatan dipegang oleh orang yang berbeda; 3) Prosedur dokumentasi: penelusuran dokumen untuk memberikan bukti bahwa transaksi dan kejadian yang telah terjadi. Diberikan nomor urut pada dokumen sebelum dokumen digunakan. Rangkapan dokumen yang dikirimkan pada bagian lain untuk proses pencatatan; 4) Kontrol fisik: kontrol untuk pengaman aktiva dengan mengamankan dalam brankas (safety deposit), pengaman berupa tembok, CCTV, alarm, kartu akses, penggunaan perangkat biometric seperti finger scan untuk pencatatan jam kerja karyawan; 5) Verifikasi internal independen: pemeriksaan yang dilakukan oleh divisi/ departemen yang tidak 
terlibat dalam proses operasi ataupun pencatatan dan pelaporan dengan cara memeriksa kesamaan dan melihat ke bukti dokumen pendukung; 6) Pengendalian sumber daya manusia: rotasi pekerjaan atau keharusan karyawan untuk cuti yang mana saat posisinya digantikan maka jika terdapat kecurangan bisa dideteksi oleh penggantinya. Memeriksa dengan teliti latar belakang karyawan dari riwayat pendidikan, referensi dari pekerjaan sebelumnya, surat kelakuan baik dan mengamati langsung pada saat wawancara.

Kecurangan (Yuniarwati et al., 2017:168) adalah tindakan tidak jujur yang sengaja dilakukan oleh seseorang dengan tujuan untuk mendapatkan keuntungan bagi dirinya sendiri namun merugikan bagi pihak lain. Berikut ini adalah gambar dari segitiga kecurangan (fraud triangle) yang dapat memicu terjadinya fraud.

Tekanan Finansial

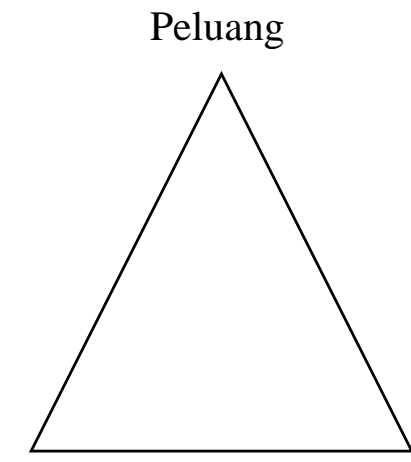

Gambar 1. Fraud Triangle

Rasionalisasi

Tiga komponen fraud (Yuniarwati et al., 2017:168) adalah:

1. Peluang: fraud akan bersotensi terjadi bila adanya peluang yang lebih besar seperti lemahnya internal control di perusahaan.

2. Rasionalisasi: seseorang akan merasionalisasi tindakannya untuk pembenaran atas kecurangan yang dilakukannya.

3. Tekanan finansial: fraud juga dapat terjadi karena adanya tekanan finansial pribadi yang tinggi.

Suatu tindakan disebut bersifat manipulatif atau kecurangan (fraud) jika memenuhi 5 kondisi (Ardana \& Lukman, 2016:66) sebagai berikut:

1. Penyajian palsu (false representation), artinya harus ada penyajian, atau pernyataan, atau pengungkapan palsu, atau ada sesuatu yang tidak diungkapkan.

2. Fakta material (material fact), suatu fakta harus cukup substansial sehingga mendorong seseorang untuk bertindak.

3. Ada niat (intent), ada maksud yang disengaja untuk menipu atau ada kesengajaan bahwa informasi yang disampaikan palsu.

4. Keterandalan yang dijustifikasi (justifiable reliance), pernyataan palsu hendaknya menjadi suatu faktor yang substansial yang dipercaya oleh pihak yang dirugikan.

5. Kerugian (injury or loss), penipuan menyebabkan kerugian bagi pihak lain yang menjadi korban.

Konsep tentang "jaminan yang memadai (reasonable assurance)" menyiratkan pemahaman bahwa sistem pengendalian internal yang diimplementasikan tidak sepenuhnya dapat menjamin/mengatasi risiko operasional, keamanan aset, serta keandalan catatan akuntansi suatu entitas, karena beberapa alasan (Ardana \& Lukman, 2016:83), yaitu:

1. Faktor lingkungan 
2. Faktor kompetensi dan integritas sumber daya manusia

3. Faktor "biaya" selalu menjadi pertimbangan utama dalam mengimplementasikan sistem pengendalian internal

Keterbatasan pengendalian internal menurut Weygandt et al. (2015:338) adalah 1) faktor manusia, jika dua atau lebih manusia bekerja sama untuk melakukan kecurangan seperti kolusi; 2) ukuran perusahaan juga dapat membatasi pengendalian internal, karena perusahaan kecil sering sulit melakukan pemisahan fungsi dan menyediakan verifikasi independen internal.

Pengendalian kas terdiri dari pengendalian penerimaan kas dan pengendalian pengeluaran kas. Pengendalian penerimaan kas (Yuniarwati et al., 2017:170) bisa dilakukan untuk penerimaan uang tunai di kasir. Pengendalian untuk penerimaan tunai bisa dilakukan dengan pemeriksaan saldo kas di kas register kasir dengan pencatatan yang tertera dalam kas register. Pada saat pergantian shift kasir, maka dilakukan serah terima dan penghitungan uang. Pengendalian pengeluaran kas akan lebih efektif bila dilakukan dengan pembayaran melalui cek atau Electronic Fund Transfer (EFT). Setiap cek/bilyet giro yang akan digunakan untuk pembayaran kepada vendor harus ditandatangani oleh bagian yang berwenang. Buku cek/bilyet giro harus disimpan di tempat yang aman agar tidak disalahgunakan. Hanya pejabat tertentu yang berhak menyetujui vendor dan memiliki ijin untuk menandatangani cek/bilyet giro. Harus ada pemisahan tugas antara yang menyetujui pembayaran, melakukan pembayaran dan melakukan pencatatan atas pembayaran.

Kas kecil atau yang sering disebut petty cash memiliki pengertian (Yuniarwati et al., 2017:171) sebagai uang tunai yang disediakan suatu usaha untuk membayar pengeluaran-pengeluaran yang jumlahnya relatif kecil dan tidak ekonomis bila dibayar dengan menggunakan cek/bilyet giro. Dokumen-dokumen yang akan digunakan dalam pengelolaan dana kas kecil adalah: 1) Bukti Kas Keluar (BKK); 2) Cek/ Bilyet Giro; 3) Permintaan Pengeluaran Kas Kecil; 4) Bukti Pengeluaran Kas Kecil; 5) Permintaan Pengisian Kas Kecil. Terdapat dua metode yang digunakan dalam pencatatan kas kecil: 1) Sistem Dana Tetap (Imprest Fund System). Metode sistem dana tetap merupakan metode pembukuan kas kecil yang mana rekening kas kecil jumlahnya selalu tetap. Setiap pengeluaran kas yang terjadi, pemegang kas kecil tidak langsung dijurnal, tetapi hanya sekedar mengumpulkan bukti transaksi pengeluarannya; 2) Sistem Dana Berubah (Fluctuating Fund System). Sistem dana berubah sering disebut juga sistem fluktuasi ataupun dana berubah. Sistem ini menghendaki bahwa jumlah nominal kas kecil tidak ditetapkan akan tetapi sesuai dengan kebutuhan.

Salah satu cara untuk mengendalikan kas (Dewi et al., 2017:157-158) adalah dengan menyimpan kas dalam rekening bank. Hal ini dikarenakan pihak bank sudah menciptakan praktik untuk menggunakan uang nasabah. Dokumen yang digunakan untuk mengendalikan rekening bank adalah: 1) Kartu Tanda Tangan; 2) Slip Setoran; 3) Cek; 4) Laporan Bank; 5) Rekonsiliasi Bank. Rekonsiliasi bank (Yuniarwati et al., 2017:179) adalah suatu prosedur pengendalian terhadap kas di bank dengan membandingkan catatan kas perusahaan secara periodik dan laporan bank. Rekonsiliasi bank dilakukan untuk menunjukkan dan menjelaskan adanya perbedaan antara catatan kas menurut bank dan menurut perusahaan. Rekonsiliasi bank dilakukan dengan tujuan menentukan saldo kas di bank yang seharusnya disajikan dalam laporan keuangan (neraca) dan mengamankan kekayaan perusahaan dan mendeteksi kemungkinan adanya penyalahgunaan kas di bank. Faktor-faktor yang menyebabkan perbedaan antara saldo kas menurut catatan perusahaan dan catatan bank: 1) Perbedaan waktu pengakuan; 2) Kesalahan pencatatan oleh bank atau oleh perusahaan 
Kas (Weygandt et al., 2016:295-298) adalah aset yang paling cepat dikonversi ke jenis aset yang lain, sehingga kas adalah aset yang paling rentan terjadinya aktivitas kecurangan. Oleh karena itu, perlu adanya pengendalian kas untuk menjaga kas dan memastikan keakuratan pencatatan akuntansi kas, keefektifan pengendalian internal atas kas adalah hal yang paling kritis. Sedangkan pengertian kas menurut (Setiawan, 2013:15) adalah uang tunai yang dipegang diperusahaan atau dalam rekening bank. Pada umumnya perusahaan memiliki banyak rekening bank dan dana kas kecil dalam jumlah tertentu, dan umumnya perusahaan menggabungkan semua jumlah kas ke dalam akun kas dan setara kas. Setara kas digabungkan dengan kas dengan tujuan pelaporan pada posisi keuangan (Dewi et al., 2017: 161).

Salah satu laporan keuangan (IAI, 2016:1.11) adalah laporan posisi keuangan dimana informasi yang disajikan dalam laporan tersebut menyajikan pos kas dan setara kas. Menurut Setiawan (2013:45-48), Laporan neraca/posisi keuangan yaitu laporan yang menunjukkan harta, liabilitas, dan modal pada suatu waktu tertentu. Kas merupakan harta yang harus dilaporkan dalam neraca. Sifat laporan keuangan menurut Kasmir (2014:11-12) adalah bersifat historis dan menyeluruh. Pencatatan yang dilakukan dalam penyusunan laporan keuangan harus dilakukan dengan kaidahkaidah yang berlaku. Demikian pula dalam hal pemyusunan laporan keuangan didasarkan kepada sifat laporan keuangan itu sendiri. Bersifat historis artinya bahwa laporan keuangan dibuat dan disusun dari data masa lalu atau masa yang sudah lewat dari masa sekarang. Kemudian, bersifat menyeluruh maksudnya laporan keuangan dibuat selengkap mungkin. Pengendalian terhadap kas meliputi pengendalian penerimaan kas dan pengeluaran kas (Dewi et al., 2017: 162). Pengendalian penerimaan kas dan pengeluaran kas dapat dilakukan melalui kas kecil dan rekonsiliasi bank. Simulasi implementasi pengendalian dan pelaporan kas dilakukan melalui praktek langsung kas kecil, rekonsiliasi bank beserta jurnal pencatatannya, dan pelaporan kas.

\section{METODE PELAKSANAAN PKM}

Metode yang dipakai dalam Pengabdian Kepada Masyarakat (PKM) ini adalah metode penjelasan materi implementasi pengendalian dan pelaporan kas, serta simulasi atau praktek dalam memahami implementasi pengendalian dan pelaporan kas untuk anak-anak SMA/SMK di Yayasan Kasih Mandiri Bersinar tersebut. Hal ini digunakan untuk mendukung misi permasalahan mitra yaitu pendampingan berkala bagi anak-anak, maka Yayasan Kasih Mandiri Bersinar merencanakan program di tahun 2018 adanya kerja sama dengan pihak luar (eksternal) untuk mendukung prestasi anak dalam bidang pendidikan di sekolahnya. Materi yang diberikan dalam Pengabdian Kepada Masyarakat di Yayasan Kasih Mandiri Bersinar terdiri dari: 1) Prinsip-prinsip Aktivitas Pengendalian Internal; 2) Kecurangan; 3) Pengendalian Kas; 4) Kas Kecil; 5) Rekonsiliasi Bank; 6) Pelaporan Kas; 7) Simulasi Implementasi Pengendalian dan Pelaporan Kas.

\section{HASIL DAN PEMBAHASAN}

Kegiatan terlaksana pada hari Minggu, 4 November 2018. Dimulai dari keberangkatan pada pukul 09.30 WIB dari Kampus Untar I, Jl. S. Parman No. 1 menuju ke Yayasan Kasih Mandiri Bersinar, Jl. Bambu Kuning No. 27 RT.008 RW.01, Kelurahan Jati Padang, Kecamatan Pasar Minggu, Jakarta Selatan. Kegiatan ini dilakukan pada hari Minggu, 4 November 2018 dari Pukul 11.0014.30 yaitu dimulai dengan acara pembukaan, pembagian modul, penjelasan isi modul, materi implementasi pengendalian dan pelaporan kas untuk anak-anak SMA/SMK yang dibina oleh Yayasan tersebut.

Pelatihan implementasi pengendalian dan pelaporan kas ini dikhususkan untuk anak-anak Yayasan Kasih Mandiri Bersinar dengan tingkat pendidikan SMA/SMK. Adapun materi pelatihan implementasi pengendalian dan pelaporan kas di Yayasan Kasih Mandiri Bersinar dibagi menjadi 
2 sesi, yaitu: a) Sesi 1: Pelatihan Implementasi Pengendalian Kas oleh Ibu Margarita Ekadjaja; b) Sesi 2: Pelatihan Pelaporan Kas oleh Ibu Henny. Setelah selesai sesi tersebut dilanjutkan dengan praktek implementasi pengendalian dan pelaporan kas dan evaluasi dari latihan tersebut.

Sesi 1 pelatihan implementasi pengendalian kas oleh Ibu Margarita Ekadjaja menjelaskan materi: 1) Prinsip-prinsip dalam aktivitas pengendalian internal. Peserta pelatihan dapat memahami pengertian pengendalian internal dan komponen dalam implementasi pengendalian internal yang digunakan dan dapat memahami enam prinsip dalam pengendalian aktivitas; 2) Kecurangan (fraud). Peserta pelatihan dapat memahami pengertian kecurangan, fraud triangle yang dapat memicu terjadinya kecurangan, dan lima tindakan bersifat manipulatif atau kecurangan; 3) Pengendalian kas. Peserta pelatihan dapat memahami pengendalian kas baik pengendalian penerimaan kas maupun pengeluaran kas.

Sesi 2 pelatihan pelaporan kas oleh Ibu Henny menjelaskan materi: 1) Kas kecil. Peserta pelatihan dapat memahami pengertian kas kecil, dokumen-dokumen yang diperlukan dalam pengelolaan kas kecil, dan metode pencatatan kas kecil; 2) Rekonsiliasi bank. Peserta pelatihan dapat memahami pengertian dan tujuan rekonsiliasi bank, faktor-faktor yang menyebabkan perbedaan antara saldo kas menurut catatan perusahaan dan catatan bank, prosedur pemeriksaaan rekonsiliasi bank, dan pencatatan jurnal penyesuaian atas rekonsiliasi bank; 3) Pelaporan kas. Peserta pelatihan memahami pengertian kas dan setara kas serta pelaporan kas; 4) Simulasi implementasi pengendalian dan pelaporan kas. Peserta pelatihan dapat mengimplementasikan pengendalian kas, kas kecil, rekonsiliasi bank beserta jurnal pencatatannya, dan pelaporan kas.

Pelatihan 2 sesi yang diberikan oleh tim pelaksana yang dibantu oleh 2 mahasiswa jurusan akuntansi Fakultas Ekonomi Universitas Tarumanagara yaitu Lucky Suvia dan Vivien dapat berjalan lancar yang didukung dengan keaktifan peserta dalam bertanya dan menjawab pertanyaan dari tim pelaksana. Pelatihan lainnya pun sangat mereka nantikan untuk memberikan pengetahuan akuntansi. Setelah pelatihan tersebut selesai, maka dilanjutkan dengan acara penyerahan sumbangan buku, alat tulis dan kalkulator bagi anak-anak tersebut. Kemudian dilanjutkan dengan penyerahan sumbangan, serta makan siang, penutupan dan foto bersama.

Anak-anak SMA/SMK di Yayasan Kasih Mandiri Bersinar yang ikut serta dalam pelatihan secara keseluruhan terdiri dari 22 orang dari 35 orang terdaftar. Sedangkan anak-anak yang tidak bisa mengikuti pelatihan ini sebanyak 13 orang dikarenakan harus menjaga anak-anak yang masih balita.

Berikut foto-foto yang terkait dengan pelaksanaan Pengabdian Kepada Masyarakat adalah: 


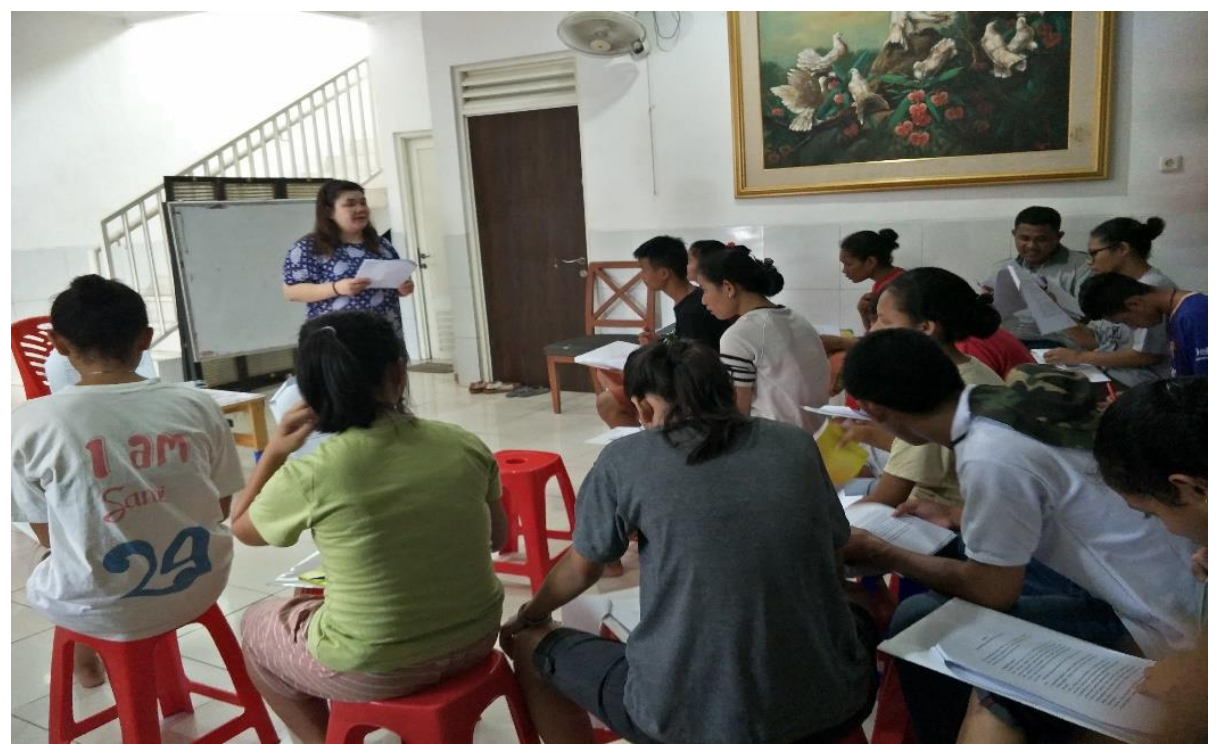

Gambar 2. Foto Pelatihan Implementasi Pengendalian Kas oleh Ibu Margarita Ekadjaja

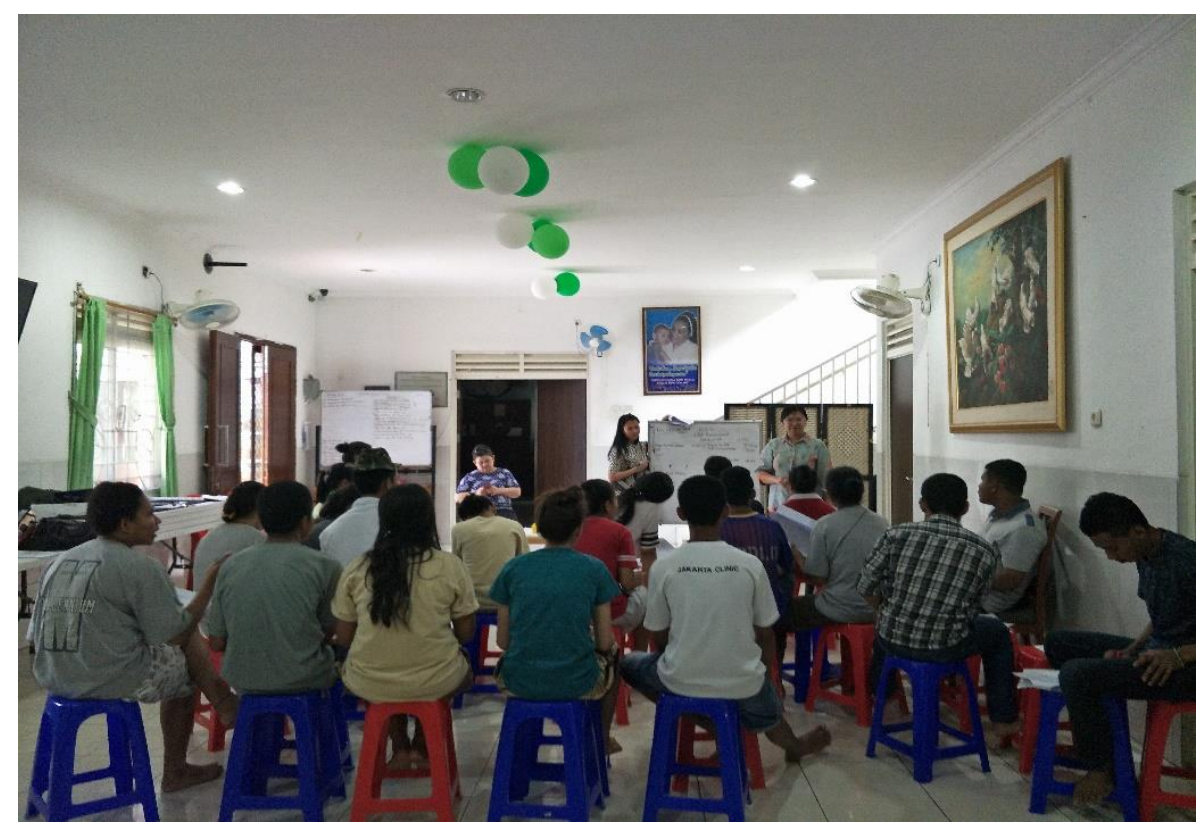

Gambar 3. Foto Pelatihan Pelaporan Kas oleh Ibu Henny 


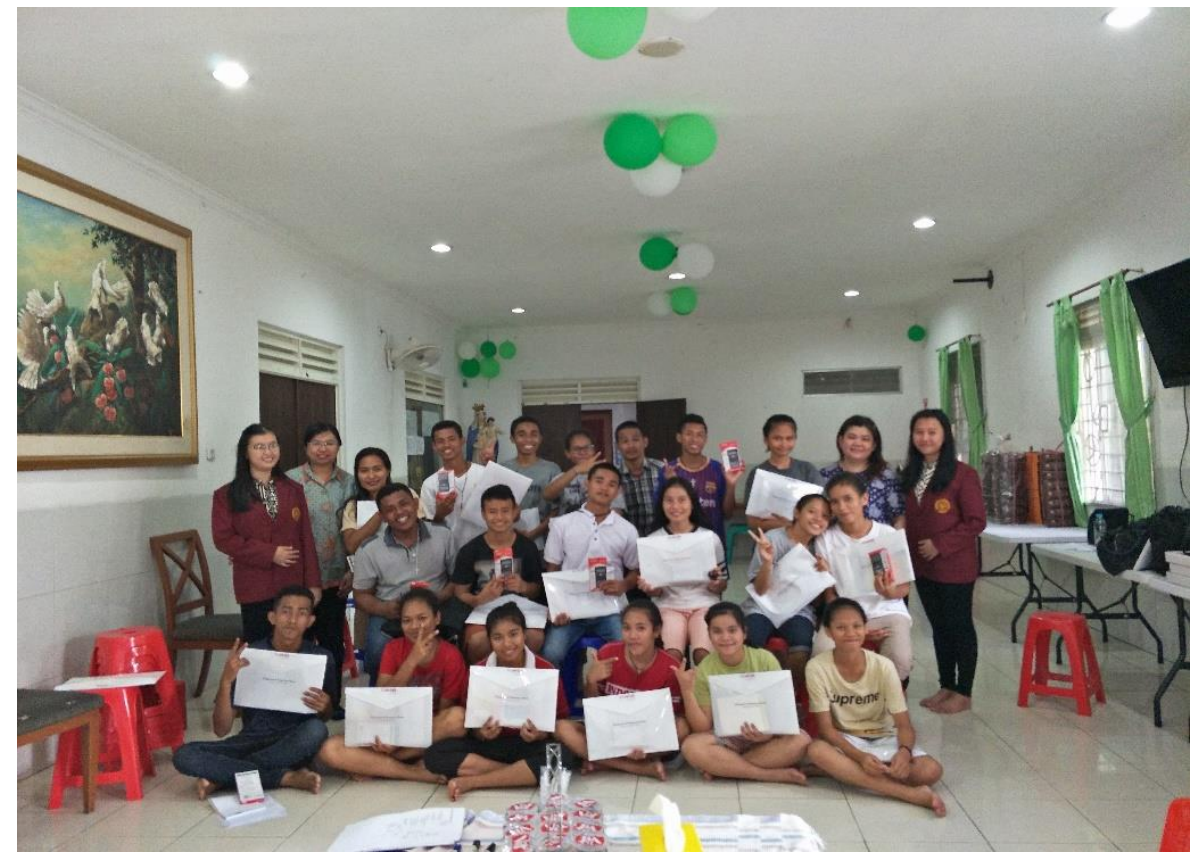

Gambar 4. Foto Bersama Tim PKM (Dosen dan Mahasiswa) dan Anak-Anak Yayasan Kasih Mandiri Bersinar

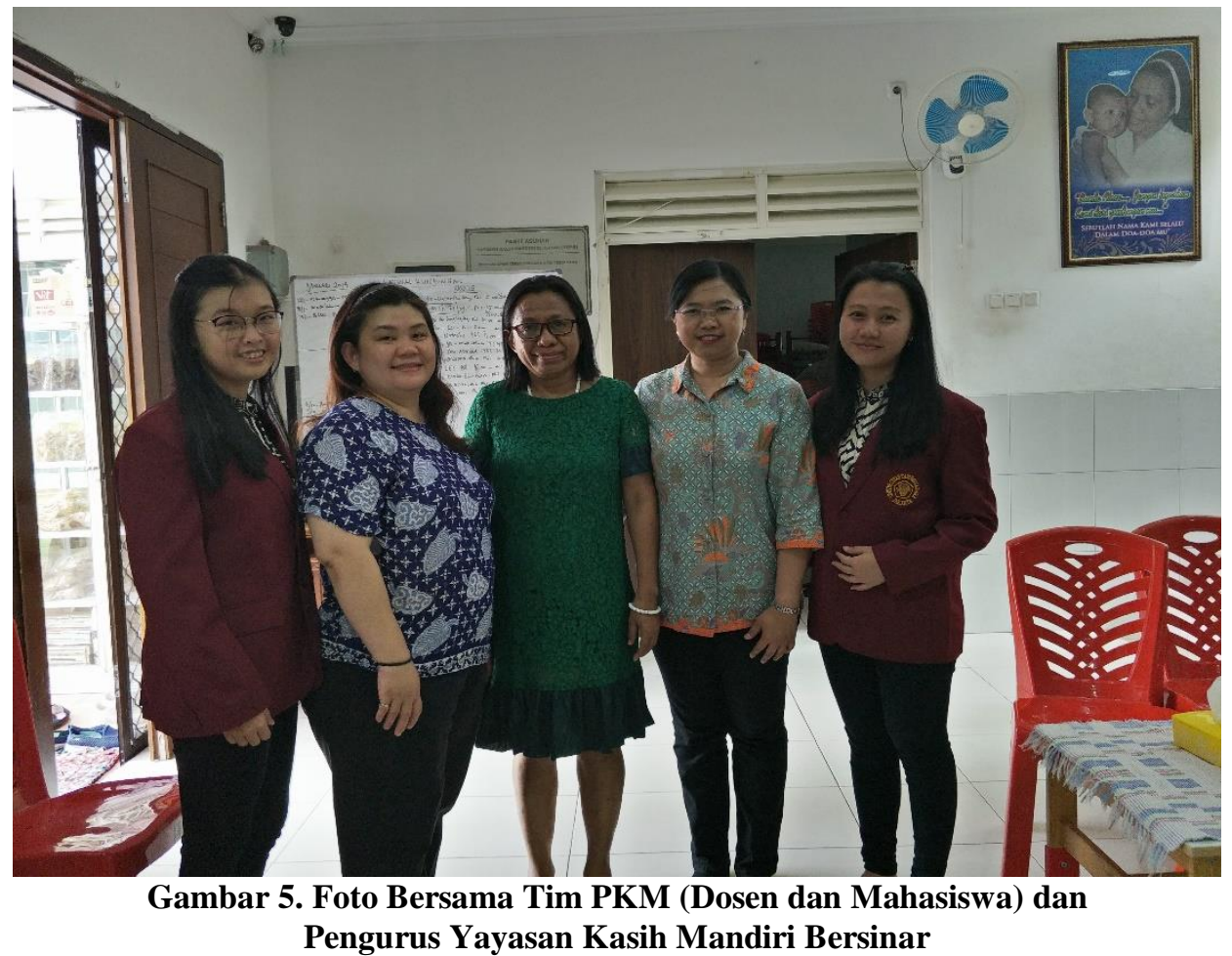

Kegiatan Pengabdian Kepada Masyarakat (PKM) ini didukung penuh oleh perguruan tinggi Universitas Tarumanagara melalui dana yang diberikan kepada tim PKM. Tim PKM adalah tim yang telah memperoleh sertifikasi dosen, sehingga setiap semester pasti akan melakukan Tri Dharma Perguruan Tinggi, salah satunya adalah kegiatan Pengabdian Kepada Masyarakat (PKM). Kegiatan PKM yang telah dilakukan tim selama empat tahun terakhir adalah kegiatan yang sesuai dengan spesialisasi bidangnya yaitu Akuntansi Keuangan, Perpajakan, dan Manajemen Keuangan. Spesialisasi bidang yang dimiliki tim dapat memberikan solusi bagi persoalan dan kebutuhan mitra 
Panti Asuhan Yayasan Kasih Mandiri Bersinar, Jakarta Selatan tentang implementasi pengendalian dan pelaporan kas.

\section{KESIMPULAN DAN SARAN}

Pelatihan implementasi pengendalian dan pelaporan kas di Yayasan Kasih Mandiri Bersinar dapat disimpulkan berjalan dengan baik. Peserta yaitu anak-anak Yayasan Kasih Mandiri Bersinar dengan tingkat pendidikan SMA/SMK sangat bersemangat dengan kegiatan ini. Hal ini dikarenakan mereka sangat membutuhkan pengetahuan dalam meningkatkan prestasi pendidikan mereka di sekolah terutama dalam mata pelajaran akuntansi yaitu pengendalian dan pelaporan kas. Pelatihan ini memberikan dampak bagi para pesertanya yang meminta tim Pengabdian Kepada Masyarakat untuk mengadakan kegiatan seperti ini berlanjut, terutama dari segi pengetahuan dan wawasan yang dapat mendukung misi Yayasan Kasih Mandiri Bersinar yaitu pendampingan berkala bagi anak-anak yang dibina dan tinggal di Yayasan Kasih Mandiri Bersinar, agar mereka dapat mandiri di masa depan.

Saran dari pelaksanaan Pengabdian Kepada Masyarakat ini adalah sebaiknya dilanjutkan dengan pelatihan berikutnya terutama untuk membantu peningkatan prestasi pendidikan anak-anak SMA/SMK di Yayasan Kasih Mandiri Bersinar.

\section{Ucapan Terima Kasih (Acknowledgement)}

Direktorat Penelitian dan Pengabdian kepada Masyarakat (DPPM) Universitas Tarumanagara yang telah memberikan kontribusi dana kegiatan Pengabdian Kepada Masyarakat dan mahasiswa jurusan akuntansi yaitu Lucky Suvia dan Vivien yang terlibat dalam kegiatan Pengabdian Kepada Masyarakat sehingga kegiatan ini dapat berjalan lancar.

\section{REFERENSI}

Ardana, I. C. \& Lukman, L. (2016). Sistem Informasi Akuntansi. Mitra Wacana Media, Jakarta.

Dewi, S. P., Sugiarto, E. \& Susanti, M. (2017). Pengantar Akuntansi Sekilas Pandang Perbandingan dengan SAK yang mengadopsi IFRS, SAK ETAP, dan SAK EMKM. In Media, Bogor.

Ikatan Akuntan Indonesia. (2016). Standar Akuntansi Keuangan Efektif Per 1 Januari 2017. Jakarta.

Kasmir. (2014). Analisis Laporan Keuangan. PT Rajagrafindo Persada, Jakarta.

Setiawan, T. (2013). Mahir Akuntansi: Buku Pengantar Akuntansi Untuk SMA dan Universitas. Edisi Revisi. PT Bhuana Ilmu Populer, Jakarta.

Weygand, J. J., Kimmel, P.D. \& Kieso, D.E. (2015). Financial Accounting IFRS Edition. Third Edition. John Wiley \& Sons Inc, US America.

Weygand, J. J., Kimmel, P.D. \& Kieso, D.E. (2016). Accounting Principles. Twelfth Edition. John Wiley \& Sons (Asia) Pte Ltd, Asia.

Yuniarwati, Santioso, L., Ekadjaja, A. \& Rasyid, R. (2017). Pengantar Akuntansi 1 Belajar Mudah Akuntansi. PT Pustaka Mandiri, Tangerang. 